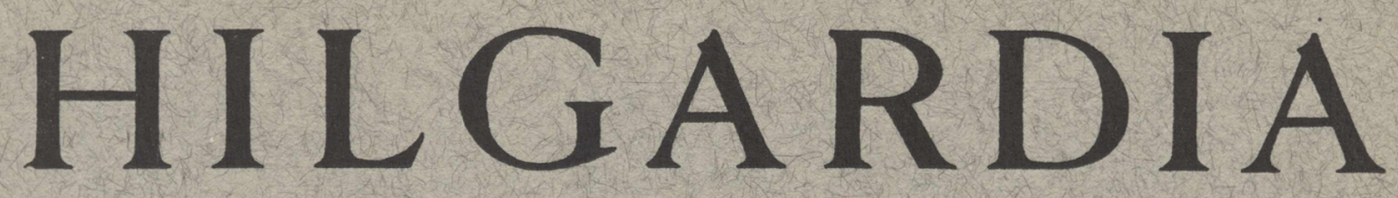

A Journal of Agricultural Science Published by the California Agricultural Experiment Station

\title{
APHID TRANSMISSION \\ OF SEVERE-MOSAIC VIRUS OF ANNUAL STOCK
}

HENRY H. P. SEVERIN and C. M. TOMPIINS

UNIVERSITY OF CALIFORNIA • BERKELEY, CALIFORNIA 


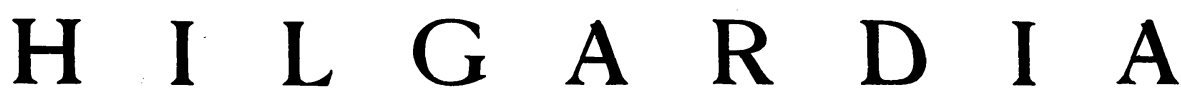

A Journal of Agricultural Science Published by

the California Agricultural Experiment Station

\begin{tabular}{l} 
Vol. $20 \quad$ AUGUST, 1950 \\
\hline APHID TRANSMISSION OF SEVERE-MOSAIC VIRUS OF \\
ANNUAL STOCK
\end{tabular}

HENRY H. P. SEVERIN ${ }^{2}$ and C. M. TOMPKINS ${ }^{3}$

\section{INTRODUCTION}

In the canyons of the Montara Mountains and the slopes along the Pacific Ocean, the mild-mosaic virus of annual stock (Matthiola incana var. annua) induces a conspicuous breaking in the color of the flower petals in all but white and yellow flowering types. The breaking renders these affected varieties unmarketable as cut flowers. A severe mosaic disease of annual stock with a striking color-breaking and conspicuous mottling and malformation of the leaves occurs in home gardens and in a nursery at San Pablo, Contra Costa County.

The turnip or false cabbage aphid, Rhopalosiphum pseudobrassicae (Davis), breeds on annual stock under natural conditions ; the cabbage aphid, Brevicoryne brassicae L., and green peach aphid, Myzus persicae (Sulzer), do not.

\section{REVIEW OF LITERATURE}

A review of the literature on virus diseases of annual stock has been published by Tompkins $(1934,1939)^{4}$ and Severin and Tompkins (1948).

A paper by Oliveira and Borges (1944) appeared and was not reviewed in our last contribution. A number of cultivated and wild crucifers, tobacco and Nicotiana glutinosa were tested, by juice inoculation, with nine isolates of an annual-stock virus from Lisbon gardens. The symptoms induced by each of the isolates on the differential hosts were mosaic, rugosity, stunting, chlorosis, necrosis, blistering, and streak.

\section{MATERIALS AND METHODS}

The virus causing severe mosaic of annual stock was obtained at San Pablo, Contra Costa County. Plants of the Fiery Blood Red variety of annual stock and the February variety of cauliflower grown from seeds were used in all experiments reported in this paper. All inoculated annual stock plants were held for observation after the flowering stage.

${ }^{1}$ Received for publication August 29, 1949.

${ }^{2}$ Entomologist in the Experiment Station, Berkeley.

${ }^{3}$ Associate Plant Pathologist in the Experiment Station, Berkeley.

"See "Literature Cited" for citations referred to in text by author and date. 
The production of colonies of noninfective aphid species has been described in a previous paper (Severin and Tompkins, 1948). The method of transferring aphids has also been'published (Severin and Freitag, 1938). The preparation of the virus from crushed, infective aphids was similar to the method described for the beet leafhopper (Circulifer tenellus Baker) (Severin and Freitag, 1938). The earborundum method (Rawlins and Tompkins, 1936 ) was used in mechanical inoculations.

\section{SYMPTOMATOLOGY OF SEVERE MOSAIC}

Tompkins (1939) has published a brief description of the foliage and flower symptoms of severe mosaic on annual stock plants. A more detailed description of the successive symptoms follows. The first symptom on the youngest leaves consists of cleared venation (plate $1, B$ ) accompanied by a bending downward of the apical end of the stem (plate $1, A$ ). Later the veins protrude on the lower surface of the younger leaves (plate $1, C$ ). Two or three weeks after inoculation a prominent coarse mottle (plate 2, B) appears on the younger leaves, which continues unchanged. The younger leaves are curled, twisted, and puckered (plate 2, $A$ ) and the intermediate leaves may be deformed (plate $2, C$ ). In the advanced stage of the disease the older leaves show a permanent mottling (plate $3, A$ ), sometimes with blisterlike elevations (plate $3, B)$. Plants infected shortly after transplanting are sometimes dwarfed.

Breaking in color of the petals consists of a conspicuous, coarse, blotched, normal color within white areas (plate $4, A$ ). Examination of individual petals shows irregular white areas scattered in the normal-colored blotches or white streaks encompassing the veins, but often spread out on each side of the veins (plate $4, B$ ).

\section{HOST RANGE OF MILD- AND SEVERE-MOSAIC VIRUSES}

The host ranges of the mild- and severe-mosaic viruses, as recorded by Tompkins (1939), include 16 species and six species respectively in the family Cruciferae; three species and one species respectively in the Chenopodiaceae; one species each in the Resedaceae; and two species each in the Solanaceae.

"Differential hosts serve as one means of differentiating the two mosaic viruses of annual stock. Susceptible to infection with the mild-mosaic virus only are Chinese or leaf mustard, pe-tsai, radish, Chinese radish, Virginia stock, honesty, sweet alyssum, wallflower, Brassica adpressa, sowbane or nettle-leaf goosefoot, Nicotiana glutinosa, and $N$. langsdorff. Infection of lambsquarters, spinach, and petunia was obtained only with the severe-mosaic virus." ('Tompkins, 1939.)

\section{PROPERTIES OF MILD- AND SEVERE-MOSAIC VIRUS}

The properties of the mild- and severe-mosaic viruses of annual stock as determined by Tompkins (1939) are as follows : Mild mosaic, aging in vitro five days, severe mosaic seven days at $22^{\circ} \mathrm{C}$; thermal inactivation of the two viruses between $58^{\circ}$ and $60^{\circ} \mathrm{C}$; and dilution one to 4,000 and one to 3,000 with the mild- and severe-mosaic viruses, respectively. 


\section{TRANSMISSION OF SEVERE-MOSAIC VIRUS}

By Unfasted, Single, Infective Aphids. The efficiency of virus transmission was determined by means of infective, unfasted cabbage and green peach aphids reared on mosaic-infected annual stock plants. Each aphid was fed singly on a healthy annual stock plant. Table 1 shows that single eabbage and turnip aphids transmitted the severe-mosaic virus to 3 and 6 per cent of the plants, respectively, but that none of the plants was infected with single green peach aphids.

Not a single infection was obtained with 200 cabbage aphids, 300 turnip aphids, and 150 green peach aphids tested singly with the mild-mosaic virus of annual stock as reported in a previous paper (Severin and Tompkins, $1948)$.

TABLE 1

TRANSMISSION OF THE SEVERE-MOSAIC VIRUS OF ANNUAL STOCK BY SPECIES OF UNFASTED, SINGLE, WINGLESS, INFECTIVE APHIDS FROM DISEASED TO HEALTHY ANNUAL STOCK PLANTS

\begin{tabular}{|c|c|c|c|}
\hline Common and scientific name of aphids & $\begin{array}{c}\text { Plants } \\
\text { inoculated }\end{array}$ & $\begin{array}{c}\text { Plants } \\
\text { infected }\end{array}$ & $\begin{array}{l}\text { Per cent } \\
\text { infected }\end{array}$ \\
\hline Cabbage aphid, Brevicoryne brassicae.......... & 100 & 3 & 3.0 \\
\hline Turnip aphid, Rhopalosiphum pseudobrassicae. . & 100 & 6 & 6.0 \\
\hline Green peach aphid, Myzus persicae........... & 100 & 0 & 0.0 \\
\hline
\end{tabular}

By Previously Noninfective, Fasted, Single Aphids in Short InfectionFeeding Periods. Previously noninfective, wingless aphids of three species were starved for two to three hours in a phial, then were fed singly on a mosaic-infected annual stock plant for one-half, one, two, five, or ten minutes, and then transferred to healthy annual stock plants. Table 2 shows that the green peach aphid and the turnip aphid transmitted the severemosaic virus to 42 and 12 per cent respectively of the plants inoculated. The cabbage aphid failed to infect any of the healthy plants inoculated after short infective feeding periods.

From Experimentally Infected to Healthy Annual Stock and Cauliflower Plants. Lots of 20 infective aphids of the three species were transferred from experimentally infected annual stock to healthy annual stock and February cauliflower plants. Table 3 shows that 32,73 , and 69 per cent of the healthy annual stock plants were infected by the cabbage, turnip, and green peach aphid, respectively, but that none of the cauliflower plants was infected.

\section{COMPARATIVE EFFICIENCY OF MECHANICAL AND APHID TRANSMISSION OF SEVERE-MOSAIC VIRUS}

Transmission of the severe-mosaic virus from experimentally infected to healthy annual stock plants by mechanical inoculation was compared with transmissions by three species of aphids. The virus extract from the infected plants upon which the aphids had fed was mechanically inoculated into healthy plants. In addition, in each test five lots of 20 aphids of each species were transferred from each infected plant to healthy plants. The results are 


\begin{tabular}{|c|c|c|c|c|c|c|c|}
\hline \multirow{14}{*}{ 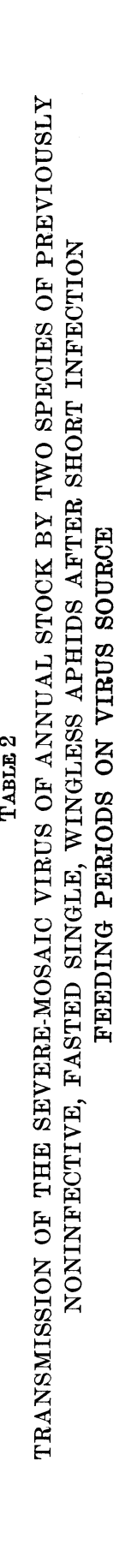 } & \multirow{3}{*}{ 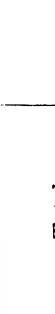 } & & 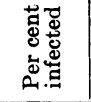 & 88 : ๙ & \multirow[b]{2}{*}{ 중 : } & \multirow{2}{*}{ 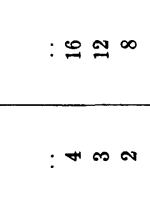 } & \multirow{2}{*}{ 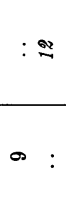 } \\
\hline & & & 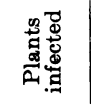 & $\stackrel{2}{2} \infty$ & & & \\
\hline & & & 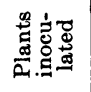 & 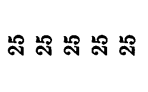 & ๙ึ: & : ลำ เ ลี & \& : \\
\hline & & 0 & 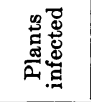 & $\forall N \infty r 0$ & $\sim \propto$ & $:$ N $\rightarrow 0$ & $\infty$ \\
\hline & & & 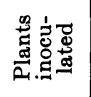 & סג סמ תמג תמג תמ & เ $:$ & סג סג סג : & $\because$ : \\
\hline & & & 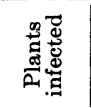 & N NONO & 0 के & $: \sim-\sigma$ & $\infty$ \& \\
\hline & 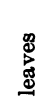 & & 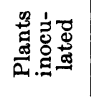 & סג סג סג סג مמ & ณ : & סג סג סג : & $\because$ : \\
\hline & 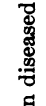 & & 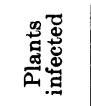 & $+x-0$ & $\cong$ & $: 0 \neg-$ & N 2 \\
\hline & 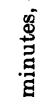 & & 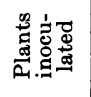 & مמ مמ תמ مג مמ & ฉ : & : & $\because:$ \\
\hline & 苯 & & 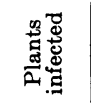 & $+\infty \infty \infty$ & $\cong \stackrel{\infty}{\sim}$ & -00 & $-\infty$ \\
\hline & 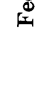 & & 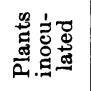 & 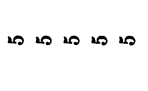 & ฉ : & תמ סמ סמ : & $\stackrel{0}{ }$ \\
\hline & & & 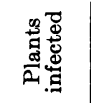 & $\pi \mu_{A N T}$ & $\therefore 8$ & $: 000$ & 00 \\
\hline & & & 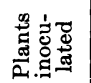 & 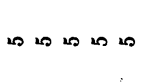 & น : & 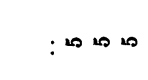 & $\stackrel{2}{2}$ \\
\hline & & 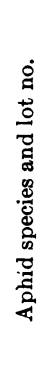 & & 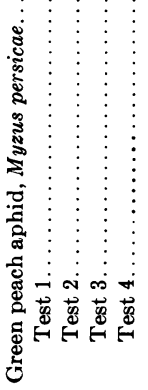 & 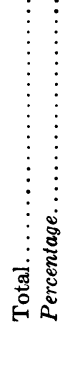 & 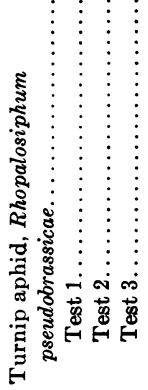 & 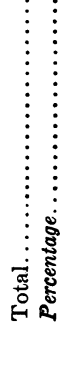 \\
\hline
\end{tabular}


TABLE 3

TRANSMISSION OF THE SEVERE-MOSAIC VIRUS FROM EXPERIMENTALLY INFECTED ANNUAL STOCK TO HEALTHY ANNUAL STOCK AND CAULIFLOWER PLANTS BY THREE SPECIES OF APHIDS, 20 IN EACH LOT

\begin{tabular}{|c|c|c|c|c|c|}
\hline \multirow{2}{*}{ Aphid species and lot no. } & \multirow{2}{*}{$\begin{array}{l}\text { Mosaic-infected } \\
\text { annual stock } \\
\text { plant no. }\end{array}$} & \multicolumn{2}{|c|}{ Annual stock } & \multicolumn{2}{|c|}{ Cauliflower } \\
\hline & & Inoculated & Infected & Inoculated & Infected \\
\hline \multicolumn{6}{|l|}{$\begin{array}{l}\text { Cabbage aphid, } \\
\text { Brevicoryne brassicae: }\end{array}$} \\
\hline 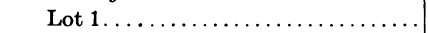 & 1 & 5 & 4 & 5 & 0 \\
\hline Lot $2 \ldots \ldots \ldots \ldots \ldots \ldots \ldots \ldots \ldots$ & 2 & $\mathbf{5}$ & 1 & 5 & 0 \\
\hline Lot $3 \ldots \ldots \ldots \ldots \ldots \ldots \ldots \ldots \ldots$ & 3 & $\mathbf{5}$ & 1 & 5 & 0 \\
\hline Lot $4 \ldots \ldots \ldots \ldots \ldots \ldots \ldots \ldots \ldots$ & 4 & $\mathbf{5}$ & 1 & 5 & 0 \\
\hline Lot $5 \ldots \ldots \ldots \ldots \ldots \ldots \ldots \ldots \ldots, \ldots$, & 5 & $\mathbf{5}$ & 1 & 5 & $\mathbf{0}$ \\
\hline 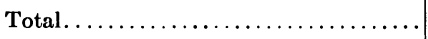 & . & 25 & 8 & 25 & 0 \\
\hline 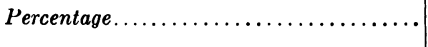 & . & . & 32 & .. & 0.0 \\
\hline \multicolumn{6}{|l|}{$\begin{array}{l}\text { Turnip aphid, } \\
\text { Rhopalosiphum pseudobrassicae: }\end{array}$} \\
\hline Lot $1 \ldots \ldots \ldots \ldots \ldots \ldots \ldots$ & 1 & $\mathbf{5}$ & $\mathbf{5}$ & 5 & 0 \\
\hline Lot $2 \ldots \ldots \ldots \ldots \ldots \ldots \ldots \ldots \ldots$ & 2 & 5 & $\mathbf{5}$ & 5 & 0 \\
\hline Lot $3 \ldots \ldots \ldots \ldots \ldots \ldots \ldots \ldots \ldots$ & 3 & $\mathbf{5}$ & $\mathbf{5}$ & 5 & 0 \\
\hline Lot $4 \ldots \ldots \ldots \ldots \ldots \ldots \ldots \ldots \ldots$ & 4 & 5 & 4 & 5 & 0 \\
\hline Lot $5 \ldots \ldots \ldots \ldots \ldots \ldots \ldots \ldots$ & 5 & 5 & 2 & 5 & 0 \\
\hline Lot $6 \ldots \ldots \ldots \ldots \ldots \ldots \ldots \ldots$ & 6 & 5 & 1 & 5 & $\mathbf{0}$ \\
\hline Total $\ldots \ldots \ldots \ldots \ldots \ldots \ldots \ldots \ldots \ldots \ldots \ldots$ & .. & 30 & 22 & 30 & 0 \\
\hline 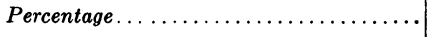 & .. & .. & 79 & .. & 0.0 \\
\hline \multicolumn{6}{|l|}{ Green peach aphid, } \\
\hline Myzus persicae: & & & & & \\
\hline Lot $1 \ldots \ldots \ldots \ldots \ldots \ldots \ldots \ldots$ & 1 & $\mathbf{5}$ & 5 & 5 & 0 \\
\hline $\operatorname{Lot} 2 \ldots \ldots \ldots \ldots \ldots \ldots \ldots \ldots \ldots$ & 2 & 5 & 5 & 5 & 0 \\
\hline Lot $3 \ldots \ldots \ldots \ldots \ldots \ldots \ldots \ldots$ & 3 & $\mathbf{5}$ & 4 & 5 & 0 \\
\hline $\operatorname{Lot} 4 \ldots \ldots \ldots \ldots \ldots \ldots \ldots \ldots \ldots$ & 4 & $\mathbf{5}$ & 4 & 5 & 0 \\
\hline Lot $5 \ldots \ldots \ldots \ldots \ldots \ldots \ldots \ldots$ & 5 & $\mathbf{5}$ & 4 & 5 & 0 \\
\hline $\operatorname{Lot} 6 \ldots \ldots \ldots \ldots \ldots \ldots \ldots \ldots \ldots \ldots$ & 6 & 5 & 1 & 5 & 0 \\
\hline Lot $7 \ldots \ldots \ldots \ldots \ldots \ldots \ldots \ldots \ldots$ & 7 & 5 & 1 & 5 & 0 \\
\hline Total $\ldots \ldots \ldots \ldots \ldots \ldots \ldots \ldots$ & . & 35 & 24 & 35 & 0 \\
\hline Percentage..................... & . & .. & 69 & .. & 0.0 \\
\hline
\end{tabular}

given in table 4 . Of the three species of aphids tested, the turnip aphid was the most efficient vector. Mechanical inoculation was more efficient in transmitting the virus : 51.4 per cent of the healthy annual stock plants became infected when mechanically inoculated; 46.7 per cent when the virus was transmitted by aphids.

\section{RETENTION OF SEVERE-MOSAIC VIRUS}

By Lots of 20 Aphids in Daily Transfers. The retention of the severe-mosaic virus was determined with three species of aphids reared on mosaic-infected annual stock plants. Lots of 20 aphids of each species were transferred daily for three days to successive healthy plants. As shown in table 5, each of the three species of aphids transmitted the virus from diseased to healthy annual stock plants during the first day only. 
By Lots of 20 Aphids with Hourly Transfers. An attempt was made to determine how long the green peach aphid retained the severe-mosaic virus. Each lot of 20 wingless aphids reared on mosaic-infected annual stock plants was transferred hourly to six successive healthy plants. As table 6 shows, one lot of green peach aphids transmitted the virus during the first two hours, eight lots during the first hour only, and one lot during the second hour only.

TABLE 4

COMPARISON OF TRANSMISSION OF THE SEVERE-MOSAIC VIRUS OF ANNUAL STOCK BY MECHANICAL INOCULATION AND BY THREE SPECIES OF APHIDS, 20 IN EACH LOT

\begin{tabular}{|c|c|c|c|c|c|c|c|}
\hline \multirow{3}{*}{$\begin{array}{l}\text { Number of } \\
\text { plants from } \\
\text { which virus } \\
\text { was recovered }\end{array}$} & \multirow{2}{*}{\multicolumn{3}{|c|}{$\begin{array}{c}\text { Mechanical inoculation } \\
\text { Annual stock plants }\end{array}$}} & \multicolumn{4}{|c|}{ Aphid transmission } \\
\hline & & & & \multirow{2}{*}{$\begin{array}{l}\text { Common and scientific } \\
\text { names of insects }\end{array}$} & \multicolumn{3}{|c|}{ Annual stock plants } \\
\hline & $\begin{array}{l}\text { Inocu- } \\
\text { lated }\end{array}$ & Infected & $\begin{array}{l}\text { Per cent } \\
\text { infected }\end{array}$ & & $\begin{array}{l}\text { Inocu- } \\
\text { lated }\end{array}$ & Infected & $\begin{array}{l}\text { Per cent } \\
\text { infected }\end{array}$ \\
\hline $7 \ldots \ldots \ldots \ldots \ldots$ & 35 & 28 & 80.0 & $\begin{array}{l}\text { Cabbage aphid, Brevicoryne } \\
\quad \text { brassicae.................. }\end{array}$ & 35 & 9 & 25.7 \\
\hline $5 \ldots \ldots \ldots \ldots \ldots$ & 25 & 11 & 44.4 & $\begin{array}{l}\text { Green peach aphid, Myzus } \\
\quad \text { persicae. } \ldots \ldots \ldots \ldots \ldots \ldots \ldots\end{array}$ & 25 & 17 & 68.0 \\
\hline $4 \ldots$ & 45 & 15 & 33.3 & $\begin{array}{l}\text { Turnip aphid, Rhopalosiphum } \\
\text { pseudobrassicae............. }\end{array}$ & 45 & 33 & 73.3 \\
\hline Total...... & 105 & 54 & $\ldots$ & & 105 & 49 & $\ldots$ \\
\hline Percentage & .. & .. & 51.4 & & .. & .. & 46.7 \\
\hline
\end{tabular}

TABLE 5

RETENTION OF THE SEVERE-MOSAIC VIRUS OF ANNUAL STOCK BY THREE SPECIES OF APHIDS, 20 IN EACH LOT

\begin{tabular}{|c|c|c|c|c|}
\hline \multirow{3}{*}{ Common and scientific names of aphids } & \multicolumn{4}{|c|}{ Aphid lots (20 each) tested } \\
\hline & \multirow{2}{*}{$\begin{array}{l}\text { Number } \\
\text { of lots } \\
\text { tested }\end{array}$} & \multicolumn{3}{|c|}{ Number transmitting virus } \\
\hline & & 1st day & $2 \mathrm{~d}$ day & $3 \mathrm{~d}$ day \\
\hline Turnip aphid, Rhopalosiphum pseudobrassicae... & 5 & 5 & 0 & 0 \\
\hline
\end{tabular}

By Previously Starved Single Aphids in Short Infection-Feeding Periods. Retention of the virus was determined more precisely with two species of aphids. Previously noninfective, wingless aphids were starved for two to three hours in a vial, then were fed singly on a mosaic-infected annual stock plant for intervals of five or ten minutes, and then were transferred at tenminute intervals to six successive healthy plants. As table 7 shows, the two species of aphids transmitted the severe-mosaic virus during the first tenminute period only.

Non-persistent Virus. Watson (1939), Watson and Roberts (1940) define non-persistent viruses as those which are easily mechanically transmissible 
and whose vectors lose their infectivity within a few hours of removal from the source of infection. The retention time of the virus by aphids is less than the time that the virus is active in extracted sap, in vitro. In the Watson and Roberts (1940) interpretation, most emphasis is put upon the effect of starvation on increase of vector efficiency.

\section{TABLE 6}

RETENTION OF THE SEVERE-MOSAIC VIRUS OF ANNUAL STOCK BY TWO SPECIES OF APHIDS TRANSFERRED HOURLY TO SIX SUCCESSIVE HEALTHY ANNUAL STOCK PLANTS

\begin{tabular}{|c|c|c|c|c|c|c|c|c|}
\hline \multirow{2}{*}{ Aphid species and lot no. } & \multirow{2}{*}{$\begin{array}{c}\text { Number } \\
\text { of aphids } \\
\text { on first } \\
\text { plant }\end{array}$} & \multicolumn{6}{|c|}{$\begin{array}{l}\text { Results* on successive plants with } \\
\text { hourly transfers }\end{array}$} & \multirow{2}{*}{$\begin{array}{c}\text { Last } \\
\text { infection } \\
\text { produced } \\
\text { by aphids, } \\
\text { hour }\end{array}$} \\
\hline & & 1 st & $2 \mathrm{~d}$ & $3 \mathrm{~d}$ & 4th & 5th & 6 th & \\
\hline \multicolumn{9}{|l|}{ Green peach aphid, Myzus persicae: } \\
\hline & 20 & + & + & - & - & - & - & $2 \mathrm{~d}$ \\
\hline $\operatorname{Lot} 2 \ldots \ldots \ldots \ldots \ldots \ldots \ldots$ & 20 & - & + & - & - & - & - & $2 \mathrm{~d}$ \\
\hline Lot 3. . & 20 & + & - & - & - & - & - & 1st \\
\hline Lot 4 . & 20 & + & - & - & - & - & - & 1st \\
\hline Lot $5 \ldots$ & 20 & + & - & - & - & - & - & 1st \\
\hline Lot $6 \ldots$ & 20 & + & - & - & - & - & - & 1st \\
\hline Lot 7. . & 20 & + & - & - & - & - & - & 1st \\
\hline Lot 8 . . & 20 & + & - & - & - & - & - & 1st \\
\hline Lot $9 \ldots$ & 20 & + & - & - & - & - & - & 1st \\
\hline \multirow[t]{3}{*}{ Lot $10 \ldots$} & 20 & + & - & - & - & - & - & 1st \\
\hline & .. & $9+$ & $2+$ & $0+$ & $0+$ & $0+$ & $0+$ & \\
\hline & $\cdot$. & $1-$ & $8-$ & $10-$ & $10-$ & $10-$ & $10-$ & \\
\hline \multicolumn{9}{|l|}{$\begin{array}{l}\text { Turnip aphid, Rhopalosiphum: } \\
\text { pseudobrassicae }\end{array}$} \\
\hline \multirow{4}{*}{$\begin{array}{l}\text { Lot } 1 \ldots \\
\text { Lot } 2 \ldots\end{array}$} & 20 & + & - & - & - & - & - & 1st \\
\hline & 20 & + & - & - & - & - & - & 1st \\
\hline & .. & $2+$ & $0+$ & $0+$ & $0+$ & $0+$ & $0+$ & \\
\hline & .. & $0-$ & $2-$ & $2-$ & $2-$ & $2-$ & $2-$ & \\
\hline
\end{tabular}

* The plus sign (+) indicates,the production of the'disease, and the minus ( - ) shows that no disease resulted

\section{LOSS AND RECOVERY OF INFECTIVITY OF TURNIP APHIDS}

An attempt was made to determine whether the turnip aphid could recover the severe-mosaic virus from inoculated annual stock plants before the first symptom developed. A large population of aphids reared on infected annual stock plants was transferred in lots of 20 aphids to healthy annual stock plants for four days. Each day, from the fifth to the fourteenth day, one lot of 20 of these aphids was transferred from the plant so inoculated to a healthy annual stock plant.

The results, reported in table 8 , show that no infections were obtained with any of the lots transferred from the fifth to the seventh day. The aphids lost infectivity after the first transfer. Infections were obtained with some lots transferred on the eighth, ninth, tenth, twelfth and later days, however; so that the aphids must have recovered the severe-mosaic virus from the first 
inoculated plants. The first symptom developed on the original inoculated plants in 13 to 31 days. The results show that the aphids were able to recover the virus from the first original inoculated plants before symptoms developed on them.

\section{TABLE 7}

RETENTION OF THE SEVERE-MOSAIC VIRUS OF ANNUAL STOCK BY SINGLE APHIDS TRANSFERRED AT 10-MINUTE INTERVALS TO SUCCESSIVE HEALTHY ANNUAL STOCK PLANTS

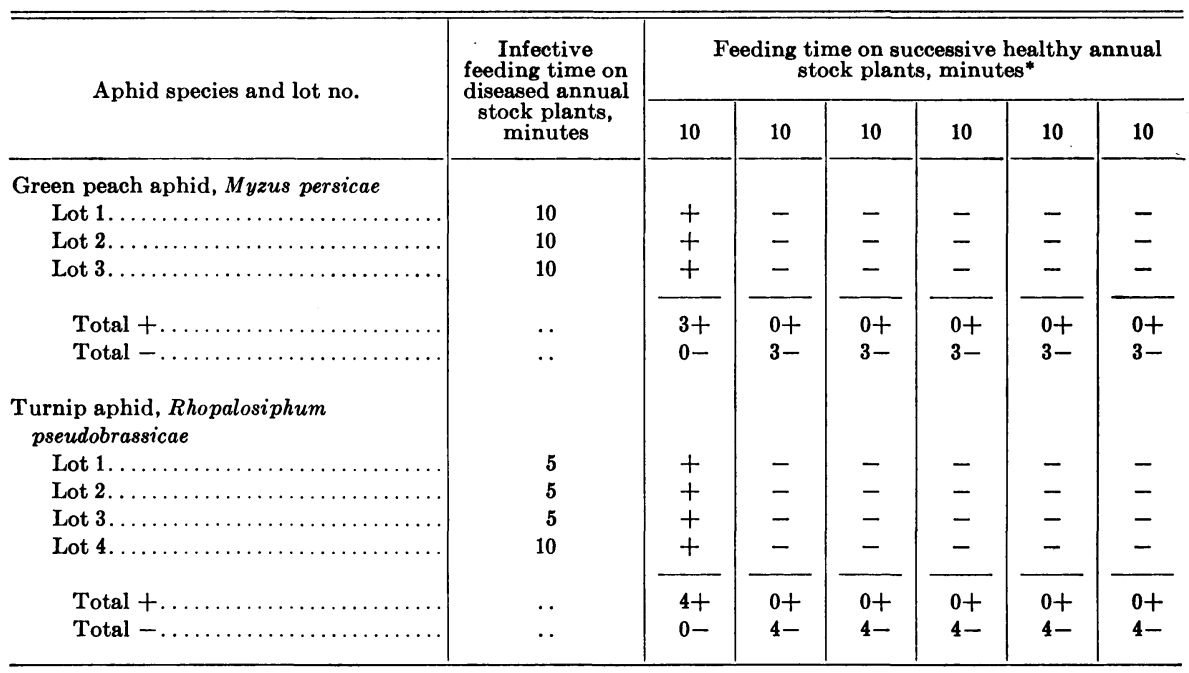

* The plus sign (+) indicates the production of the disease, and the minus sign (-) shows that no disease resulted.

TABLE 8

LOSS AND RECOVERY OF INFECTIVITY OF TURNIP APHID, RHOPALOSIPHUM PSEUDOBRASSICAE, ON ANNUAL STOCK PLANTS INOCULATED WITH THE SEVERE-MOSAIG VIRUS

\begin{tabular}{|c|c|c|c|c|c|c|c|c|c|c|c|}
\hline \multirow{2}{*}{ Original plant number } & \multicolumn{10}{|c|}{$\begin{array}{c}\text { Elapsed time in days between inoculation of each plant } \\
\text { with infective aphids and transfer, in da.ly } \\
\text { lots of } 20 \text {, to healthy plants* }\end{array}$} & \multirow{2}{*}{$\begin{array}{l}\text { Days to the } \\
\text { first symptom } \\
\text { on original } \\
\text { plant }\end{array}$} \\
\hline & $\mathbf{5}$ & 6 & 7 & 8 & 9 & 10 & 11 & 12 & 13 & 14 & \\
\hline $1 \ldots \ldots \ldots \ldots \ldots \ldots \ldots \ldots \ldots$ & - & - & - & + & - & + & + & - & - & + & 13 \\
\hline $3 \ldots \ldots \ldots$ & - & - & - & - & - & + & + & - & + & + & 25 \\
\hline $4 \ldots \ldots \ldots \ldots \ldots \ldots \ldots$ & - & - & - & - & - & - & - & + & - & + & 31 \\
\hline
\end{tabular}

* The plus sign ( + ) indicates the production of the disease, and the minus $(-)$ sign shows that no disease resulted. 


\section{MECHANICAL INOCULATION WITH SEVERE-MOSAIC- VIRUS EXTRACT FROM CRUSHED TURNIP APHIDS}

An attempt was made to transmit the severe-mosaic virus of annual stock with the extract of crushed, infective turnip aphids by mechanical inoculation of healthy annual stock plants. The virus extract prepared from one gram of infective aphids crushed in $9 \mathrm{cc}$ of sterile distilled water was inoculated in ten healthy annual stock plants. The experiment was repeated five times. A total of 50 plants were inoculated, but no infection occurred.

\section{SUMMARY}

Infective, unfasted cabbage aphids (Brevicoryne brassicae L.), and the turnip or false cabbage aphid (Rhopalosiphum pseudobrassicae Davis), tested singly, transmitted the severe-mosaic virus of annual stock to 3 and 6 per cent of the healthy annual stock plants (Matthiola incana var. annua) respectively, but in similar tests none of the plants were infected by the green peach aphid (Myzus persicae Sulzer).

When the cabbage and turnip aphids were fasted for two to three hours, fed one-half, one, two, five, or ten minutes on the leaves of infected annual stock plants, and then transferred to healthy annual stock plants, the turnip aphid infected 42 per cent and the green peach aphid 12 per cent of the plants inoculated.

The three species of aphids failed to infect cauliflower with the severe stockmosaic virus.

Mechanical inoculation (51.4 per cent) was more efficient than transmission of the severe-mosaic virus by three species of aphids.

In tests on the retention of the severe-mosaic virus, lots of 20 cabbage, turnip, and green peach aphids transmitted the virus during the first day, but none of the lots tested produced infection during the second and third days. In hourly transfers, one lot of green peach aphids transmitted the virus during the first two hours, eight lots during the first hour only, and one lot during the second hour only. The turnip aphid transmitted the virus during the first hour only. In ten-minute-period transfers, the green peach and turnip aphids transmitted the virus during the first interval only.

The severe-mosaic virus was lost during the fifth day (the first day of transfer) by lots of 20 infective turnip aphids, but was recovered during the eighth to the twelfth and later days, before the earliest symptom developed on inoculated plants, at periods varying from 13 to 31 days. The aphids were able to recover the virus from the first original inoculated plants before symptoms developed on them.

The severe-mosaic virus of annual stock is of the non-persistent type in the aphid vectors. 


\section{LITERATURE CITED}

D'Oliveira, Marie de L., and Maria de L. Borges.

1944. (Study of crucifer virus. II. Strains isolated from Matthiola incana (L.) R. Br.) Bol. Soc. Broteriana Ser. 2, $19: 265-72$.

RAwlins, T. E., and C. M. Tompkins.

1936. Studies on the effect of carborundum as an abrasive in plant virus inoculations. Phytopathology, 26.(6) :578-87.

Severin, H. H. P., and J. H. Freitag.

1938. Western celery mosaic. Hilgardia $11(9): 493-558$.

SEverin, H. H. P., and C. M. TOMPKINS.

1948. Aphid transmission of mild-mosaic virus of annual stock. Hilgardia 18(15):53952.

TOMPKINS, C. M.

1934. Breaking in stock (Matthiola incana), a virosis. (Abstract.) Phytopathology 24 (10) :1137.

1939. Two mosaic diseases of annual stock. Jour. Agr. Res. 58(1):63-77.

WATSON, M. A.

1940. Studies on the transmission of sugar-beet yellows virus by the aphis, Myzus persicae (Sulz.) Roy. Soc. London Proc. Ser. B, 128:535-52.

WAtson, M. A., and F. M. RoBerts.

1939. A comparative study of the transmission of Hyoscyamus virus 3 , potato virus $\mathrm{Y}$ and cucumber virus 1 by the vectors Myzus persicae Sulz., M. ciroumflexus Buckton, and Macrosiphum gei Koch. Roy. Soc. London Proc: Ser. B, 127:543-76. 


\section{PLATES}





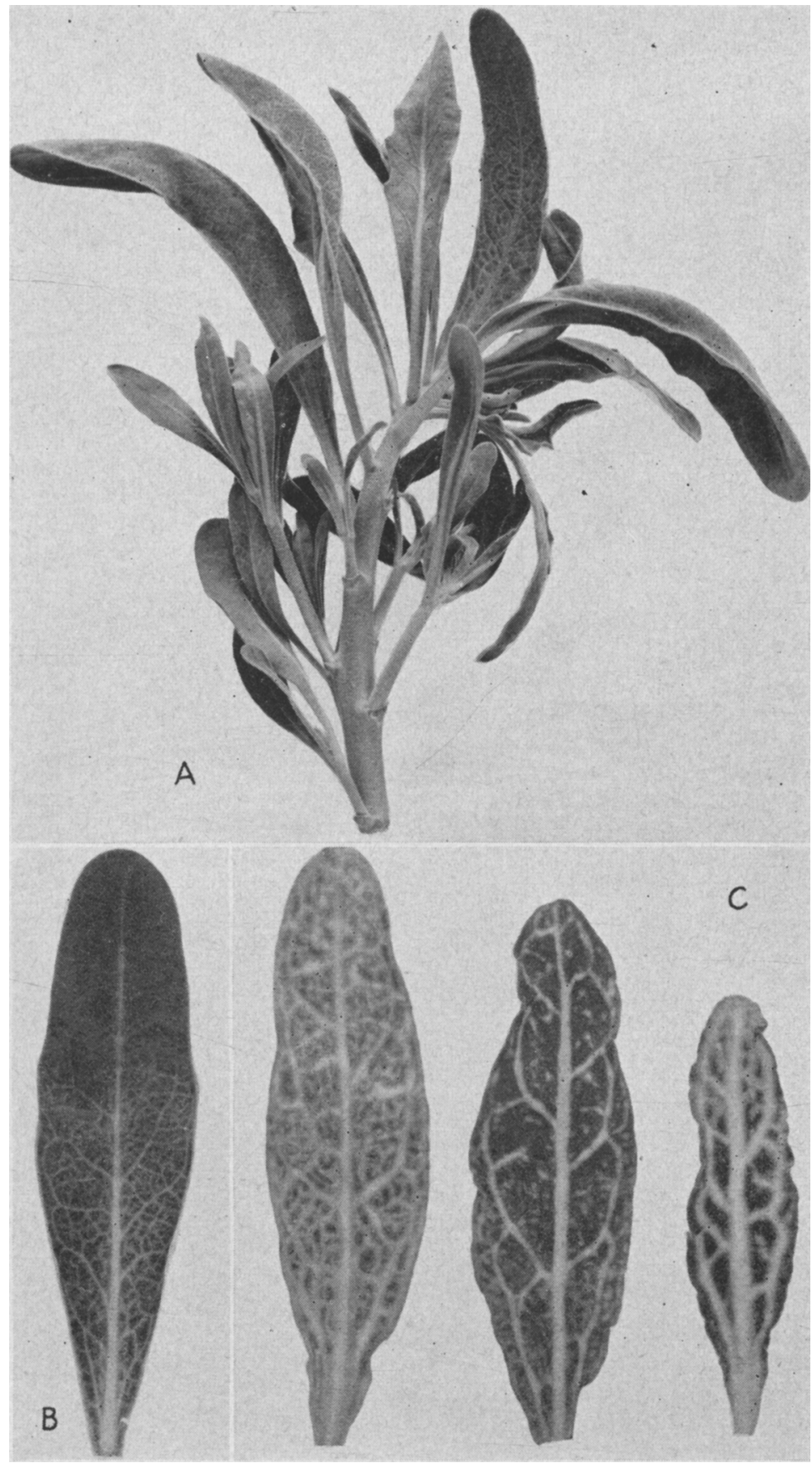

Plate 1. Early symptoms of severe-mosaic virus of annual stock (Matthiola incana var. annua) on the variety Fiery Blood Red: $A$, downwardbending of apical end of stem; $B$, cleared veinlets on youngest leaf; $C$, lower surface of younger leaves showing protruding veins, 


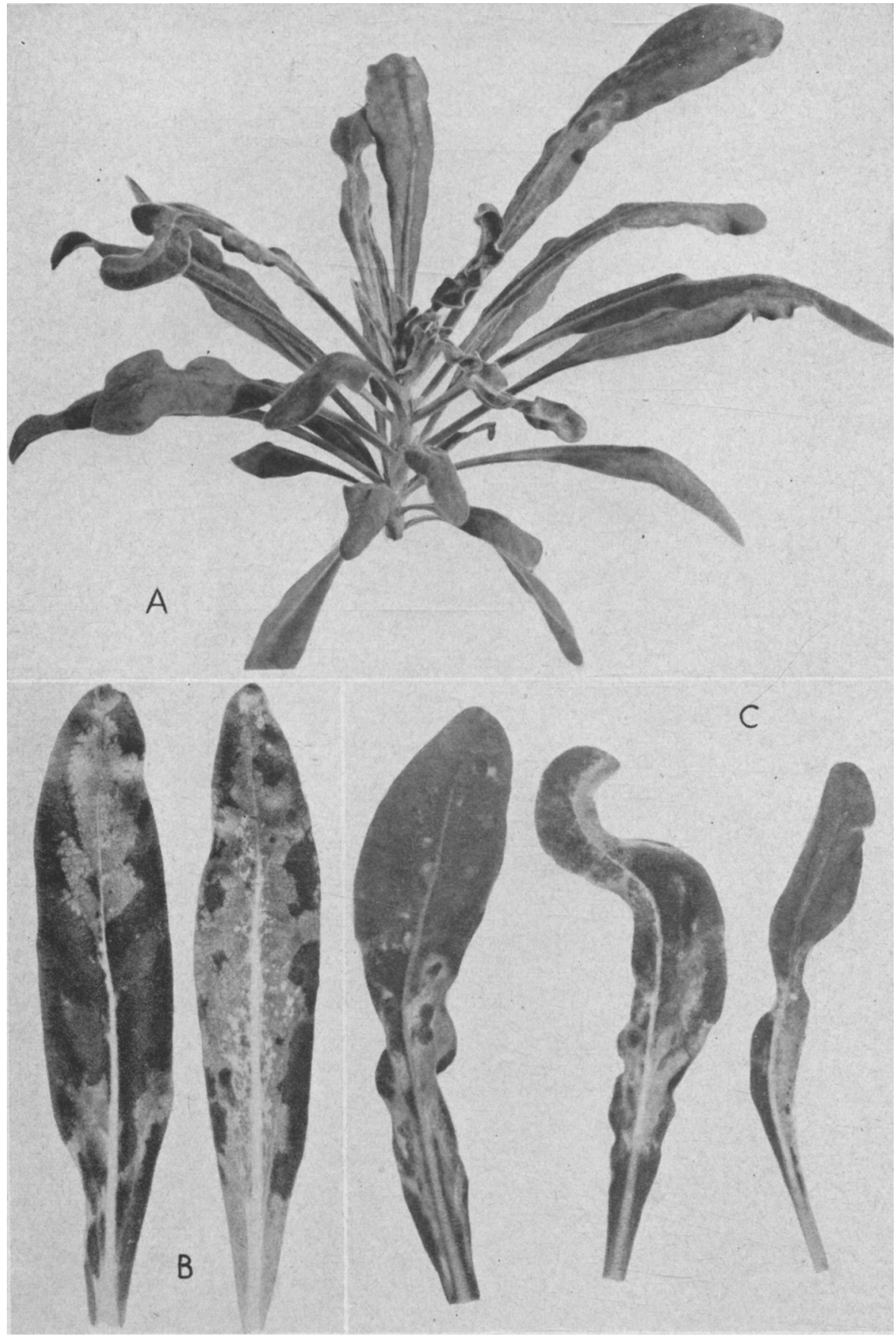

Plate 2. Symptoms induced by severe-mosaic virus of annual stock (Matthiola incana var. annua) by mechanical inoculation: $A$, infected plant showing deformed intermediate leaves, curled, twisted, and puckered younger leaves, and stunting; $B$, mottling; $C$, deformed leaves. 


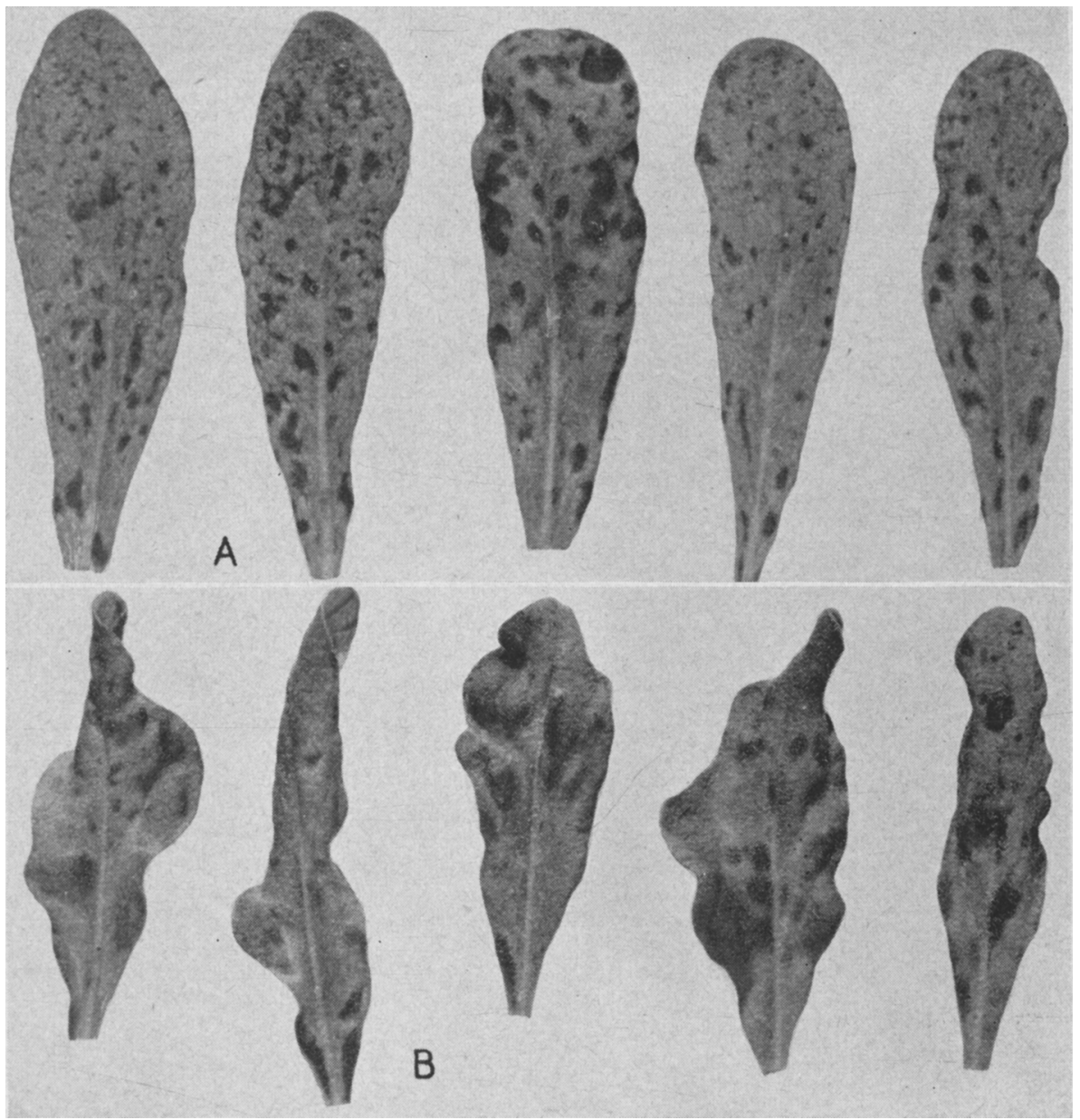

Plate 3. Advanced stage of severe-mosaic virus of annual stock (Matthiola incana var. annua) on the variety Fiery Blood Red: $A$, leaves showing mottling; $B$, leaves showing blisterlike elevations. 


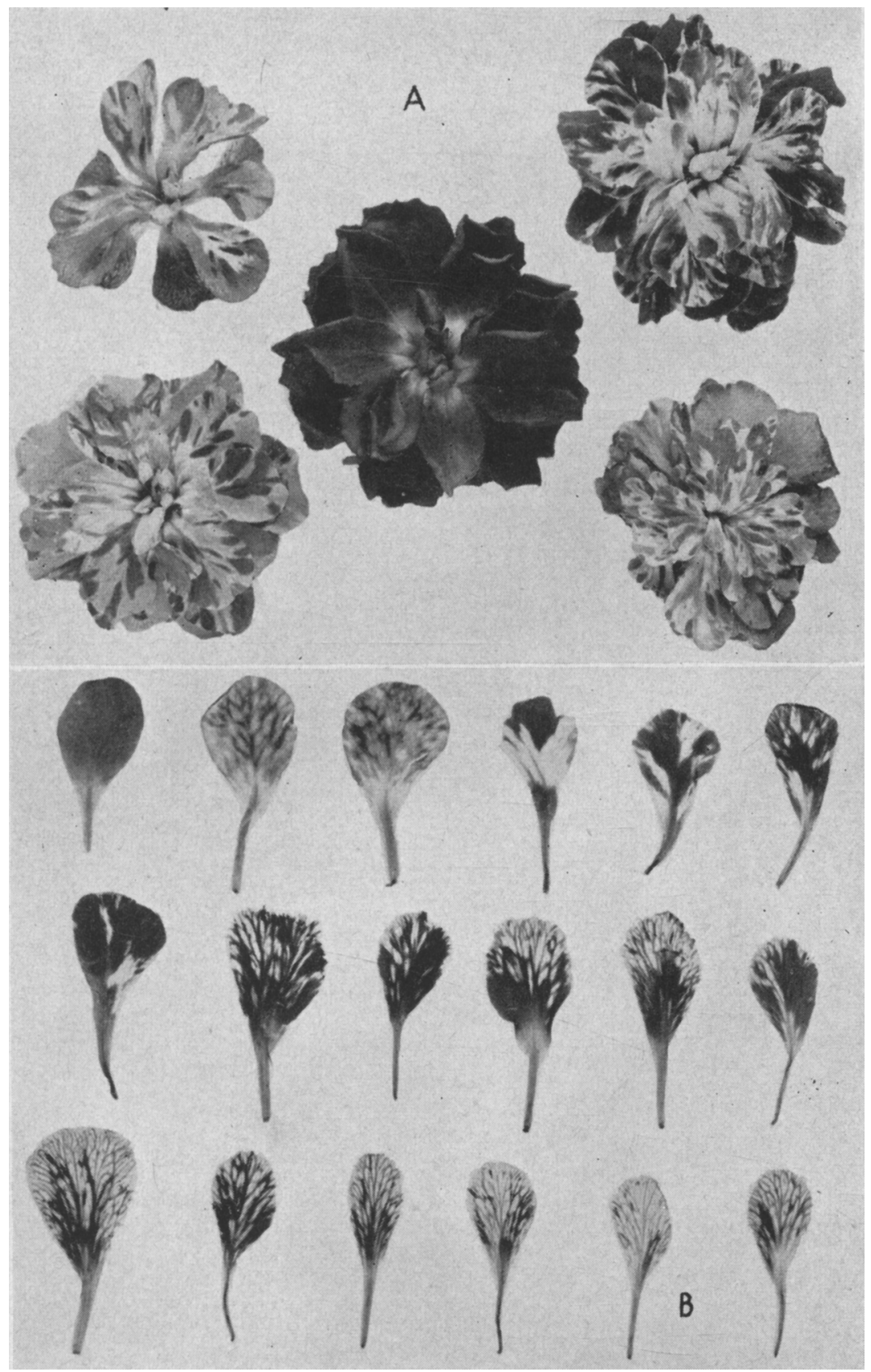

Plate 4. Symptoms induced by the severe-mosaic virus of annual stock (Matthiola incana var. annua) on flowers of naturally infected annual stock: $A$, nornal flower; grouped around it are four flowers showing breaking, consisting of coarse, blotched, normal color with white streaks on petals. $B$, petals showing breaking in color: upper row, irregular white areas scattered in normal color; middle row, white streaks encompassing veins; lower row, white streaks spreading out on each side of veins (San Pablo, Contra Costa County, July 15, 1936). 
The journal Hilgardia is published at irregular intervals, in volumes of about 600 pages. The number of issues per volume varies.

Subscriptions are not sold. The periodical is sent as published only to libraries, or to institutions in foreign countries having publications to offer in exchange.

You may obtain a single copy of any issue free, as long as the supply lasts; please request by volume and issue number from:

\section{Publications Office \\ College of Agriculture \\ Berkeley 4, California}

The limit to nonresidents of California is 10 separate issues on a single order. A list of the issues still available will be sent on request. 